For published version see: European Journal of Criminology:

https://doi.org/10.1177\%2F1477370820913456

\title{
Violence and the Crime Drop
}

Soenita M. Ganpat ${ }^{1}$, Laura Garius ${ }^{2}$, Andromachi Tseloni ${ }^{2}$ and Nick Tilley ${ }^{3}$

${ }^{1}$ Corresponding author: Soenita M. Ganpat, Department of Criminology and Social Sciences, University of Derby, Derby, UK, Email: s.ganpat@derby.ac.uk, +44 (0)1332 593445

${ }^{2}$ Department of Sociology, Nottingham Trent University, Nottingham, UK

${ }^{3}$ Jill Dando Institute, University College London, UK

\section{Introduction}

Many types of crime have fallen across many jurisdictions since the early 1990s, after inexorable rises following the Second World War (Tonry, 2014; Van Dijk and Tseloni, 2012). Since crime fell first in the United States, the early literature on the crime drop focused on trends in violent crime and the special conditions there that might explain the drop (Blumstein, 2000; Blumstein and Wallman, 2000). It has now become clear that the crime drops are widespread, albeit their timing has varied across crime types and countries (Tseloni et al., 2010). As a result, explanations that speak to conditions in particular countries have become less persuasive (Tonry, 2014). Moreover, very general explanations about overall crime falls are threatened by the increases that occurred in a small number of specific crime types (Farrell, 2013). We need to be able to explain the general patterns and variations within that general pattern, if we are to fully understand the trends. However, Aebi and Linde (2012) caution that researchers must first establish that there has been a drop in different types of crime before attempting to provide explanations. 
Evidence remains mixed regarding the pervasiveness of falls in non-lethal violence (Tonry, 2014). A first step to address this inconclusiveness is to disaggregate violence types and victim populations, as well as single and repeat victimisation trends. Early analysis suggested that a reduction in repeat violent victimisation drove the falls in violent crime in England and Wales between 1995 and 2006/07 (Thorpe, 2007): however, more recent evidence is lacking. Moreover, personal crimes are now more concentrated on the most vulnerable victims than before the crime drop (Ignatans and Pease, 2016). This raises the issue of distributive justice (Rawls, 1999), specifically, vertical equity in the case of the crime drop - those at highest victimisation risk should experience the largest crime falls (Hunter and Tseloni, 2016) - and has not been examined for violence to date.

The current study addresses the gaps identified above and investigates specifically nondomestic, non-fatal violent crime trends in England and Wales from 1991 to 2013/14, disaggregating:

- Violence types in relation to (a) the victim-offender relationship; and (b) whether the event resulted in wounding; and

- Victim populations by (a) sex and (b) age.

This work draws on victimisation survey data - the Crime Survey for England and Wales $(\mathrm{CSEW})$ - which is the only source of consistent crime estimates in England and Wales over time; police recorded crime varies due to changes in crime definitions, public's reporting and police recording practices (Van Dijk and Tseloni, 2012). Although crime concentration is best gauged from crime survey data, incidents reported to the survey by the same victim were until recently capped at five (ONS, 2018). This led to criticisms that crime rates have been kept superficially low and crime concentration underestimated (Farrell and Pease, 2007; Walby et al., 2016).

The following four questions are addressed in this study: 
I Has violence fallen in a similar manner across violence types?

II Has violence fallen to the same extent across different demographic groups?

III Is the fall in violence driven by a reduction in victimisation risk or crime concentration?

IV Has the capping of crime counts at five incidents affected these trends, and if so how?

An overview of previous work on the crime drop with a specific focus on violence trends is provided next followed by a discussion of the data source and methodology of this study. Thereafter, the main patterns of the non-domestic violent crime drop are described. This article ends with some initial hypotheses that might explain the variations in violent crime trajectories found here which may inform future work into what caused them.

\section{Previous studies on violence and the crime drop}

How it all started and potential explanations of the crime drop

The crime drop phenomenon is described as "the most important criminological issue of modern times" (Farrell et al., 2015: 16). The drop is even more remarkable as it began against a backdrop of steady increases in overall crime post the Second World War (Eisner, 2008; Farrell et al., 2010; Gurr, 1981; LaFree et al., 2015). Moreover, a decade of dramatic increases in violence directly preceded the crime drop (Machin and Meghir, 2004). Described as the "flood of violence" (Pinker 2011: 107), the 1980s and early 1990s were characterised by the steepest recorded increase in violent offences since records began (Machin and Meghir, 2004; Mooney, 2003: 104). Experts on both sides of the Atlantic warned that the 1990s and 2000s would be characterised by ballooning crime rates and "30,000 more young muggers, killers and thieves" (Wilson, 1995 cited in The Economist, 2011). As such, the dramatic downward trajectory of violent crime was both unexpected and unprecedented (Aebi and Linde, 2014; Britton et al., 2012; Hall, 2013) and continues to present 
criminologists with 'uncomfortable questions' around the cause of the decline (Knepper, 2015: 59).

Tonry (2014: 1) notes that a drop in violence should be seen everywhere as good news: "Fewer people are victimised. Fewer are arrested, prosecuted, convicted, and punished. Hospital emergency rooms handle fewer intentional injuries. Insurance companies compensate fewer losses". At the same time, major concerns have been raised that the UK crime drop is neither well documented, nor in the public's consciousness (Mooney and Young, 2006). Tonry (2014: 1) states that, "almost no one except a handful of academic specialists" has recognised the decline of crime throughout the western world. The concern is even more pronounced since emerging research proposes that the descent of violence has now come to an end (Walby et al., 2016). As a result, there is a fear of trend-reversal, which heightens the incentive to understand sub-trends and correlates of violent crime to both sustain the decline, and to forestall increases (Farrell et al., 2014).

Towards explaining the crime drop

Several notable attempts have been made to explain the crime drop. A viable crime drop hypothesis needs to successfully explain both the 'striking uniformity' of the international trend (Van Dijk et al., 2007) as well as a number of specific variations in the way that crime fell (Farrell 2013). To elaborate, variation is observed between countries, whereby substantial drops in violent and property crime were experienced across most of continental Europe, the United Kingdom, United States, Canada and Australia (Tseloni et al., 2010). However, Switzerland and Sweden experienced an anomalous increase in crime over the same period (Killias and Lanfranconi, 2012). Whilst there is little disagreement that property crime (including rates of burglary, theft, motor vehicle theft) has been falling since the 1990s across industrialised countries (Baumer and Wolff, 2014; Farrell et al., 2014; Lappi-Seppala and 
Lehti, 2014; Van Dijk and Tseloni, 2012), the international evidence remains mixed regarding the pervasiveness of falls in non-lethal violence (Tonry, 2014).

Farrell (2013) suggests a total of five criteria that an adequate crime theory must satisfy; including specific variations in the timing, depth and trajectory of declines observed both between countries, and within-countries. Existing hypotheses have been grouped into the following categories: (1) classic theories, which draw on variables repeatedly and historically linked to crime (e.g. improvements in economic conditions and waning drug markets (Morgan, 2014)); (2) punitive responses, which look to the criminal justice system and policies and agencies of law enforcement; (3) motivated offender theories, which propose a net reduction in the stock of crime-prone individuals; (4) civilising processes, which hypothesise self-control to be the mechanism of crime decline; and (5) opportunity theories, which at micro, meso and macro level, suggest that behavioural and environmental changes reduced the number of opportunities for crime to occur.

Theories dominating the global crime drop rhetoric typically fail to explain betweencountry variation as they draw on distinctly U.S. developments, including gun control, policing innovation, capital punishment, abortion legalisation, and a reduction in childhood exposure to lead (Tonry, 2014). In addition, those theories proposing either a net reduction in the overall offending population or a change in the propensity of offenders to commit crime fail to explain why crime decline varies between crime types. A notable exception are opportunity theories $^{l}$ which are uniquely able to accommodate both the uniformity of, and variation within, this international trend (Farrell, 2013). Situational principles and interventions are argued to have a direct influence on the opportunity structure of crimes (Cornish and Clarke, 1986), the stock of criminogenic opportunities, and the aggregate crime rates (Farrell et al., 2005). From an opportunity perspective, Tilley et al. (2015: 60) concluded that three principles have governed fluctuations in the stock of criminogenic 
opportunities: (1) intended improvements in security (through the increased quantity and quality of security measures and changes to environmental design); (2) unintended improvements in security (capturing the debut and keystone sub-theories of the 'security hypothesis', suggesting that a reduction in opportunities for one crime type reduces opportunities for other crime types (Farrell et al., 2015)); and (3) unintended effects of routine activities (including changing lifestyles and technological progress).

The role that security has played in reducing the stock of crime opportunities and hence the number of crime events - the 'security hypothesis' - has been examined in relation to the drops in vehicle crime (Farrell et al., 2011a), burglary (Tseloni et al., 2017), and personal theft (Thompson, 2014). However, research concerning changes to the opportunity structure and the drop in violent crime "is in its infancy" (Farrell et al., 2015: 17). Traditional criminological interpretations wherein violence is seen as 'irrational' and impervious to environmental cues (Hayward, 2007) continues to challenge the view that violence is in any way opportunity-driven. However, a growing body of evidence serves to highlight the rational, or 'decisional' nature (Felson, 2012: 206) of violence. Reasoned decisions are evident in offenders' choice of location, weapon and victim (Felson, 1997; Felson and Steadman, 1983). It is suggested that "sound judgments of victim suitability and guardian proximity defines a reasoned choice" (Farrell et al., 1995: 386), for example, an assessment of physical superiority is almost universally made by the aggressor (Felson, 1996; Indermaur, 1999).

In addition, violence is subject to cues in the immediate environment and can be regarded as a 'situated event' (Hebenton, 2011: 143) patterned by the routine activities of daily life and the convergence in space and time of a motivated offender and a suitable target, in the absence of capable guardianship (Cohen and Felson, 1979). Opportunities for violence are not equally distributed in space and time, with certain environments being conducive to 
violence: for example, $16 \%$ of licensed venues experience $60 \%$ of licensed venue crime (Scott and Dedel, 2006). Opportunities for violence are also seen to concentrate against individuals with certain socio-demographic characteristics and lifestyles that increase their exposure to risk (Hindelang et al., 1978).

Changes in lifestyles and routine activities, such as increased time spent in public places, especially at night, have successfully explained the rise in post WWII violence crossnationally (Cohen and Felson, 1979; Aebi and Linde, 2014; Killias and Lanfranconi, 2012). Aebi and Linde (2014: 569) identify another major lifestyle shift in the 1990s relating "to the reunification of the European continent as well as the development of computer technologies and the Internet" which they link to cross-national decreases in homicide beginning in the early 1990s. This shift altered lifestyles by increasing the amount of time spent at home especially salient for young people who could afford video games and later, a household internet connection (Griffiths and Sutton, 2015; Aebi and Linde, 2014).

\section{Previous studies of violence trends across crime subtypes}

There are some indications that violence has fallen in a dissimilar manner across violence types. Put differently, within violent crime itself, variation has been observed between categories of violence. For example, Felson (1997: 210) observed that "the specific routine activities usually associated with domestic violence are not likely to be the same as those associated with street crime... activities that draw people away from their home are not likely to increase violence in the home". Also, Walby et al., (2016: 1224) demonstrated that "the trajectory of domestic violence is different to that of other forms of violent crime". Furthermore, in the night-time economy context, violence between acquaintances has experienced a steeper decline than violence between strangers over the course of the crime drop (Garius, 2016). 
Previous studies of violence trends across different population groups

Previous research also indicates that there are inequalities in violent victimisation-risk across different population groups. Concretely, there are indications that "the crime drop might apply to some social categories of victims and perpetrators rather than others" (Walby, Towers and Francis, 2016: 1205). Adolescent offending has been recognised as the driving force behind both the rapid increase and subsequent decline of violence (Cook and Laub, 2002; Farrell et al., 2015). However, there is little evidence concerning drops in crime across different population groups and changes in inequalities in victimisation- and offending-risk (Hunter and Tseloni, 2016; Nilsson et al., 2017). The criterion for investigating the distributive justice of the crime drop is vertical equity: "the unequal, but equitable, treatment of unequals" (Mooney and Jan, 1997: 80), whereby the most victimised groups experienced the greatest crime falls thereby reducing victimisation inequalities. This study begins to fill this gap in relation to overall falls in violent crime by focusing on the patterns of change in levels of violent crime across demographic groups whose members face unequal risks.

Overall, the literature highlights the need to disaggregate violence. The present study will therefore empirically examine the trajectories and sub-trends associated with non-lethal violence in England and Wales. It explores variation in the decline in violence disaggregated by (1) severity of violence, (2) victim-offender relationship, (3) victim demography, and (4) whether reductions in victimisation risk or crime concentration have driven these trends. Therefore, the present work is among the first attempts to empirically examine the distribution of the violent crime drop.

\section{Data and method}


The following analysis uses eighteen data sets of the Crime Survey for England and Wales (CSEW) to examine violence trends from 1991 to 2013/14. The CSEW (formerly the British Crime Survey) is a face-to-face survey originally administered by the Home Office (19822011/12) and since 1 April 2012 by the Office for National Statistics (ONS). It is based on a stratified multi-stage cross-section sample design with continuous annual rotation. The samples are representative of the adult (16 years and over) population in England and Wales ${ }^{2}$ and the survey has maintained high response rates while response rates for other social surveys are declining (Tilley and Tseloni, 2016). The CSEW has employed annual rotating samples of roughly 40,000 respondents per year in England and Wales since 2001/02. Previous sweeps had used cross-section sampling of about 20,000 respondents with the bulk of the fieldwork completed between January and March of each survey year during the 1980's and 1990's. Thus, crime counts based on the CSEW refer to the calendar year prior to the fieldwork for all sweeps up to the 2001/02 CSEW and the financial year (April to March) indicated by the CSEW data set thereafter. This is evident in the charts and ONS tables delineating crime trends in England and Wales as will be so throughout this study.

ONS publications include both police recorded crime and CSEW estimates of crime trends; however, as highlighted in these publications (see for example: ONS, 2017), only the CSEW estimates are reliable. To be more precise, offence definition changes, variations in the public's reporting to the police and police recording practices render police recorded crime unsuitable for examining crime trends (Van Dijk and Tseloni, 2012) with the exception of homicide. Homicide figures are universally held as the most reliable measurement of crime: both because the indicator is unambiguous and because trends can be validated by health statistics data (Tonry, 2014; Ariel and Bland, 2019). For other crime types, police recorded crime in England and Wales is a measure of police activity rather than a reliable source for the scale of crime problems (Tilley and Tseloni, 2016). As a result, those interested 
in examining the crime drop and crime trends in general, where possible, rely on crime survey data (Tilley and Tseloni, 2018). In England and Wales, the CSEW has employed consistent crime definitions since its inception in 1981 to record the public's experiences of crime and provides our official national statistics on crime.

In order to ensure the survey's representation of the adult population in England and Wales "a number of weights ${ }^{3}$ (based on calibration of population estimates originally from the Labour Force Survey and currently the 2011 Census) are provided" (Tilley and Tseloni, 2016: 83). Sample-based crime counts are projected to national estimates via the use of weights that redress any sampling biases originating, for example, from limited survey access to 'hard to reach' populations (Tilley and Tseloni, 2016). The analysis reported here draws from truncated and untruncated weighted (using the individual CSEW weight) data as they have been recently re-calibrated by the ONS (ONS, 2015).

The CSEW records crimes that have been experienced by the respondent in the screener module of the main questionnaire module which is administered to the entire sample. Respondents who reported victimisation(s) are then asked to complete the Victim Form (VF) module. The VF includes questions that allow reliable offence classification of the reported incident and gather detailed information about the circumstances and context of each particular incident; offender(s) characteristics, perceived alcohol and drug consumption, and modus operandi, if known to the victim; detailed information about the effects and consequences of the incident; and whether the crime was reported to the police and/or victim support groups, victim satisfaction and outcome of the reporting and other incident-based information.

Based on the VFs information, the CSEW can gauge the relationship between victim and offender(s) classifying violence across three categories: stranger, acquaintance and domestic. Stranger violence occurs in incidents where the victim did not know the offender(s) 
and had never seen any of the offender(s) before. Acquaintance violence occurs when the victim knew one or more of the offenders at least by sight (e.g. neighbours and local children, colleagues, clients or members of public contacted through work, friends and acquaintances), excluding household members or (ex-)intimate relationships. Finally, domestic incidents occur when the violence is perpetrated by a household member, within intimate relationships or by a partner or ex-partner. As mentioned, domestic incidents are not examined in this study. Furthermore, rare events including robbery, sexual violence and attempted murder are also omitted from this research due to limitations in the sample reach (Flatley, 2014). The VFs also provide information on the incident's outcome with regards to physical assault that enable distinctions to be made between violence with wounding - i.e. serious wounding, other wounding, and serious or other wounding with a sexual motive - and violence without wounding or common assault.

Each victim is asked to complete up to six VFs. This implies that the CSEW did not record more than six crimes within a year per respondent over the period examined in this study ${ }^{4}$. VFs are completed per reported crime incident in order of crime seriousness, and violence - being the highest seriousness crime type in the CSEW - takes precedence over any other reported crime type (ONS, 2017). This implies that nearly all violence incidents reported by victims in the screening questions are counted. However, should an individual be a victim of more than six violent incidents considered to be different in nature, these surplus incidents are disregarded in the CSEW crime estimates. This explains why we referred earlier to 'nearly all'. In addition, if six or more recurring victimisations are of a similar nature, under similar circumstances and possibly committed by the same offender(s) against the same victim (called 'series crimes'), then the number of crimes is truncated at five and detailed information is gathered only about the most recent incident (Farrell and Pease, 2007; Tilley and Tseloni, 2016). Both CSEW policies are justified to ensure that crime estimates are not 
heavily influenced by a relatively small proportion of the sample made up of very heavily victimised individuals and households (Tilley and Tseloni, 2016). Therefore, VFs based crime estimates do not include in their counts of violent incidents those where individuals report (a) seven or more incidents of violence that are different from one another, and (b) six or more violent incidents forming a series.

In this study, the focus is on the capped series from the VFs which provide the truncated $^{5}$ violence trends and are examined in detail across violence type and victim age and sex. The uncapped series which are taken from the VFs provide untruncated violence trends estimates. These, in effect, include the number of incidents within series where more than 5 incidents were reported and are compared to the capped series. For clarity, only truncated trends are presented in the text unless otherwise noted. As mentioned, one reason for truncation is that a small number of highly victimised respondents in any sweep can massively affect the estimates and hence produce fluctuations in apparent trends. It should be noted that although using untruncated data more accurately reflects the suffering experienced by chronic victims, they create some problems for analysis (also they substantially affect concentration in ways that are liable to be unstable due to the effect of small numbers and happenstance in sampling). Caution is therefore warranted in interpreting the untruncated data. Consequently, untruncated trends are not shown here, unless a different conclusion would follow from the comparison between truncated and untruncated trends which can be found in the Appendix. Violence is measured in this study via three rates: (a) incidence which indicates the average number of violent incidents per 100 individuals (16 years old or older); (b) prevalence which gives the number of victims of violence per 100 individuals; and (c) concentration, the average number of violent incidents per victim. ${ }^{6}$ All crime rate measurements are necessary to examine the level of crime in a society and they complement one another: The incidence rate indicates how much violent crime occurs per 100 individuals. 
Prevalence (divided here by 100) measures the likelihood of becoming a victim of violence. Concentration, which is the ratio of incidence over prevalence or the number of crimes over the number of victims, shows how frequently victims suffer violence within a year. Incidence is made up by prevalence and concentration. In other words, crime counts reflect both the number of victims and how many crimes each victim experienced. This link is used to address the third research question: Is the fall in violence driven by a reduction in victimisation risk or crime concentration?

The analysis that follows distinguishes (i) whether the assailant was a stranger or an acquaintance, (ii) whether injuries were or were not sustained during the incident, (iii) violent crime experienced by men and women, and (iv) violent crime experienced by those in different age groups. The overall differences in violent crime rates between sub-groups are noted in each case prior to describing trends. In each case the (truncated and untruncated) incidence rates are shown, alongside estimates of the other two crime measurement components that show whether the main driver of the identified trend was a change in (a) prevalence or (b) concentration. This is achieved by calculating the following: hypothetical trends in prevalence rates assuming that the concentration rate has remained at the same level as in the study's initial year, 1991; and concentration trends as if prevalence was constant at 1991 levels. An example of the methodology used here follows. If, for instance, crime incidence and prevalence rates for the initial year were 10 and 5 per cent (or 0.10 and 0.05), respectively, the base concentration rate would have been 2 crimes per victim on average $(0.10=0.05 \times 2)$. Let us assume that the following year the incidence rate falls to 8 per cent. The hypothetical prevalence rate, assuming the concentration rate has remained at the same base level, is therefore 4 per cent (calculated as $0.08 / 2$ ). The hypothetical concentration rate corresponding to constant crime prevalence levels at the base year is 1.6 crimes per victim (calculated as $0.08 / 0.05$ ). Similar calculations using the respective 1991 prevalence and 
concentration rates as a base were undertaken across all violence types over the period examined here. The trends analysis therefore is exploratory but not entirely descriptive. In the next findings' section, we also discuss whether the observed falls in violence rates over time are statistically significant (via independent sampling tests of difference of means for incidence and concentration rates and difference of proportions for prevalence rates (McClave and Sincich, 2017) using unweighted sample size, as recommended by the ONS), alongside the rate of these falls.

\section{Findings}

The findings are organised around seven subsections comparing different violence types and victim populations via time series graphs (Figures 1-9). In Figures 1-3, 5-7 and 9 black lines give truncated trends, lines with circles reflect incidence rates, solid lines show prevalence rates and dotted lines indicate crime concentration. The main text focuses on truncated incidence trends; untruncated trends shown via grey lines (in Appendix Figures 1-5) feature in the discussion insofar as their patterns differ from the truncated ones. Appendix Table 1 summarises the falls in truncated (along with their statistical significance) and untruncated incidence rates and hypothetical (assuming constant violence concentration at 1991 levels) prevalence rates across different violence types and victim populations.

\section{Acquaintance and stranger violence}

To discern violence victimisation trends, we first distinguished whether the assailant was a stranger or an acquaintance (Figure 1). Acquaintance violence peaked earlier than stranger violence (1995 compared to 2002/03, respectively; $\mathrm{p}<.001$ ) and dropped by 73 per cent: from 4.2 incidents per 100 adults (16+ years old) in 1995 to 1.1 per 100 adults in 2013/14 $(\mathrm{p}<.001)-$ its lowest level in the past two decades. Stranger violence dropped by 43 per cent 
from its 2002/03 peak of 2.4 incidents to its lowest level of 1.4 per 100 adults in 2013/14 $(\mathrm{p}<.001)^{7}$. Although in 1995 there were almost twice as many incidents perpetrated by acquaintances than by strangers, by 2013/14 stranger violence slightly exceeded acquaintance violence. Therefore, their relative contribution to overall violence reversed. The main driver for the declines in both violence types was a reduction in the number of victims rather than crimes per victim.

Capping violence counts at five incidents per victim did not affect acquaintance violence trends - truncated and untruncated trends were similar and driven by changes in prevalence - but precipitated stranger violence falls. Untruncated (uncapped) stranger violence incidence rates peaked later than truncated (capped) ones (2006/07 and 2002/03, respectively, $\mathrm{p}<.05$ ) and their fall, overall, was attributable to a reduction in crime concentration (Appendix Figure 1).

[FIGURE 1 HERE]

\section{Acquaintance violence victimisation incidence with and without wounding}

Distinguishing acquaintance violence in relation to crime severity, Figure 2 indicates that both components peaked in 1995 but acquaintance violence without wounding was consistently higher and declined faster than acquaintance violence with wounding. Specifically, acquaintance violence without wounding decreased by 79 per cent from 3.2 crimes per 100 adults in 1995 to 0.7 in 2013/14 $(p<.001)$. Acquaintance violence with wounding declined by 66 per cent from 0.9 crimes per 100 adults to 0.3 during the same period $(\mathrm{p}<.001)$. Falls in both components reflected fewer victims over time (solid line, Figure 2) rather than changes in the number of crimes each victim experienced.

Capping crime counts only resulted in a non-significant two-year delay in the fall of acquaintance violence with wounding (Figure 2 and Appendix Figure 2).

[FIGURE 2 HERE] 
Acquaintance violence victimisation incidence against men and women

Figure 3 separates acquaintance violence trends against men and women. Men were consistently more victimised by people they knew but also experienced faster declines than women. Acquaintance violence against men fell by 77 per cent from its peak ( 6.2 crimes per 100 adult men) in 1995 to its lowest point $(1.4)$ in 2013/14 $(\mathrm{p}<.001)$. Acquaintance violence against women peaked earlier, in 1993, at 2.5 crimes per 100 adult women and declined by 64 per cent to 0.9 in $2013 / 14(p<.001)$. Fewer men and women were victimised by someone they knew (solid line, Figure 3) but victims of either sex continued to experience the same number of incidents over time. The victimisation (incidence) gap between male and female victims approximately halved during the study period - from $3.4(=3.7 / 1.1)$ in 1991 to 1.6 $(=1.4 / 0.9)$ in $2013 / 14$ but it remained statistically significant. These patterns did not alter significantly when examining the uncapped crime counts, despite steeper falls in acquaintance violence against men and greater fluctuations in that against women, largely driven by changes in concentration.

\section{[FIGURE 3 HERE]}

Acquaintance violence victimisation incidence across age groups

Disaggregating acquaintance violence by different age groups, Figure 4 demonstrates that 1644 year olds have consistently experienced more such crimes as well as greater falls than those aged $45+$ years old. Specifically, acquaintance violence against 16-24 year olds fell by 83 per cent from its peak of 16 incidents per 100 young adults in 1995 to 2.7 in 2013/14 $(\mathrm{p}<.001)$. Over the same period the decline was 72 per cent (from 5.5 to 1.6 incidents per 100 individuals $25-34$ years old $)$ for the second age group $(\mathrm{p}<.001)$. Acquaintance violence against 35-44 year olds also fell by 72 per cent between 1993 and 2009/10 (from 4.1 to 1.1 incidents per 100 individuals in this age group, respectively; $\mathrm{p}<.001$ ). The victimisation incidence gap between 16-24 year olds and those aged 25 and over narrowed over time. 
Additionally, the gap between the youngest two groups and those aged 35-44 also narrowed over time (from 6.8 and 1.6 in 1991 to 9.1 and 1.1 in 2013/14, respectively). Also, the gap between 35-54 and 55-64 narrowed since 1995.

Figure 5 shows that the falls were driven by both fewer victims and fewer crimes per victim in the youngest age group, as their hypothetical (at 1991 prevalence levels) concentration fell by 36 per cent between 1991 and 2013/14 (from 9.5 to 6.1 incidents per young adult victim, respectively; $\mathrm{p}<.001)$. By contrast, the decline in acquaintance violence against 25-34 year olds was entirely driven by fewer victims over time, whilst concentration increased by 25 per cent (the increase between 1991 and 2013/14 was not statistically significant; $\mathrm{p}=.066)^{8}$

\section{[FIGURES 4-5 HERE]}

\section{Stranger violence victimisation incidence with and without wounding}

Turning our attention to different types of stranger violence, Figure 6 shows that stranger violence without wounding was consistently higher than with wounding and mirrored trends in prevalence rather than crime concentration. It fell by 50 per cent from its peak (in 1995 and 1999) of 1.7 stranger violence without wounding incidents per 100 adults to 0.9 in $2012 / 13$ $(\mathrm{p}<.001)$. Stranger violence with wounding declined by 59 per cent from its peak $(0.7)$ in $2002 / 03$ to its lowest level $(0.3)$ in $2013 / 14(p<.001)$.

Capping crime counts at five incidents per victim created a non-significant delay in the start of stranger violence falls by four years (2003/04 instead of 1999 for stranger violence without wounding and 2006/07 rather than 2002/03 for that with wounding, Figure 6 and Appendix Figure 3). ${ }^{9}$ However, changes in crime concentration have driven the untruncated incidence rates trends of stranger violence with wounding over the entire study period and those without wounding from 2003/04 onwards. Interestingly, untruncated concentration 
(assuming 1991 prevalence levels) of stranger violence without wounding was 37 per cent higher in 2013/14 than in 1991; however, the difference was not statistically significant (Appendix Figure 3; $p=.06$ ).

\section{[FIGURE 6 HERE]}

\section{Stranger violence victimisation incidence against men and women}

Disaggregating trends in stranger violence by sex, Figure 7 shows that men are more victimised than women. Stranger violence incidence rates against men fluctuated considerably from 2002/03 onwards around an overall 46 per cent fall; the difference between the 2002/03 highest (4.1 crimes per 100 adult males) and the 2013/14 lowest (2.2) levels was statistically significant $(\mathrm{p}<.001)$. Stranger violence against women - which peaked later at 1.1 such crimes per 100 adult females in 2006/07 - dropped by 48 per cent at 0.6 in $2013 / 14(p<.001)$. The gap between male and female victimisation incidence narrowed slightly over time (from $3,9(=3.1 / 0.8$ in 1991 to $3.7(=2.2 / 0.6)$ in $2013 / 14$ ), but the difference has remained statistically significant $(\mathrm{p}<.001)$. The victimisation gap between $16-$ 24 and 25 or older narrowed over time. The two youngest groups in relation to those $35-44$ year olds also narrowed over time (from 4.5 and 2.4 in 1991 to 2.6 and 1.6 in 2013/14, respectively).

Capping crime counts shifted the year of the lowest stranger violence incidence against men backwards and reduced its level. The uncapped rate was at its lowest in 2007/08, with the difference from the $2013 / 14$ capped rate being statistically significant $(p<.001)$. Although trends in capped stranger violence incidence against men were driven by changes in prevalence, the uncapped trends were influenced by concentration (Figure 7 and Appendix Figure 4). Furthermore, untruncated concentration (assuming 1991 prevalence levels) of stranger violence against men was 37 per cent higher in 2013/14 than in 1991 ( $p<.001$; Appendix Figure 4). Conversely, untruncated and truncated incidence trends in stranger 
violence against women were similar, despite several fluctuations in untruncated trends, equally caused by prevalence and concentration.

[FIGURE 7 HERE]

\section{Stranger violence victimisation incidence by age groups}

Age patterns of stranger violence incidence rates showed a slow decline over time for all age groups except those aged 35-44 and 55-64 years old. ${ }^{10}$ Younger individuals (16-34 years old) were consistently more victimised by strangers than those aged $35+$ years old, but also enjoyed significant crime falls (Figure 8) owing to changes in prevalence rather than crime concentration (Figure 9). Stranger violence against 16-24 year olds dropped by 51 per cent from 7.4 incidents per 100 young adults in $2001 / 02$ to 3.7 in $2013 / 14$ ( $p<.001$ ); whereas incidents against 25-34 year olds fell by 49 per cent (from 3.9 in 1997 to 2.0 incidents per 100 adults in this age group in 2012/13) over a longer period $(\mathrm{p}<.05)$.

\section{[FIGURE 8 HERE]}

Capping crime counts brought forward and smoothed the stranger violence fall against young adults (16-24), but these disparities (Figure 9 and Appendix Figure 5) were not statistically significant. ${ }^{11}$ In contrast to the truncated data, but similarly to the other untruncated stranger violence series already discussed, untruncated stranger violence incidence against 16-24 year olds was driven by changes in concentration (Figure 9 and Appendix Figure 5).

\section{[FIGURE 9 HERE]}

The next and final section discusses the theoretical and policy implications of these findings with tentative future research suggestions to understand the causes of these drops. 


\section{Conclusion and Discussion}

This is one of the first pieces of work that dissects trends in stranger and acquaintance violence by sex, age, and the presence of injury, using CSEW estimates using ONS calibrated weights. In this final section, we summarise the findings around the four research questions and their implications.

\section{Has violence fallen in a similar manner across violence types?}

This study evidenced that all violence components examined here by (a) victim-offender relationship (excluding domestic incidents) and (b) severity fell significantly over time, without any sign of reversal in the period examined ${ }^{12}$. However, they followed different trajectories. Acquaintance violence incidence rates peaked in 1995 before showing an overall decreasing trend. Stranger violence incidence rates peaked in $2002 / 03$, remained stable in 2003/04 and thereafter fell slowly. Notwithstanding international evidence of a delay in the drop in violence compared to acquisitive crime (Tonry, 2014; Tseloni et al., 2010), the above findings suggest that acquaintance violence closely mirrored the trajectory of acquisitive crime in England and Wales. Stranger violence fell eight years later; similar to the observed delay of international violence falls compared to acquisitive crime (Tseloni et al., 2010). At a closer examination, the trajectory of aggregate violence rates in England Wales predominantly reflected trends in acquaintance violence (ONS, 2019; Tseloni, 2016)

Stranger violence falls were substantial but less pronounced than falls in acquaintance violence; as a result, the share of incidents among strangers within all violence has increased over time. Acquaintance and stranger violence trajectories also differ in relation to crime severity. Acquaintance violence incidence trends closely followed falls in incidents without wounding (Figures 1 and 2). Stranger violence trends initially followed the trajectory of incidents without wounding (first peak in 1995) but from 1999 onwards trends in incidents 
with wounding (peak in 2002/03, Figures 1 and 6). Therefore, the delayed aggregate stranger violence fall mentioned earlier was the result of a later drop in high severity incidents (with wounding) among strangers.

These findings highlight the importance of disaggregating overarching trends identified in the existing literature, and the error of addressing 'violence' as one homogeneous crime type. A central assumption of situational crime prevention is crime specificity (Clarke, 1997; Cornish, 1994), suggesting that opportunity structures differ between crime types. Clarke and Cornish (1985) recommend the analysis of distinctive crime types to develop specific preventative measures "which in turn increase[s] the success of intervention" (Ozer and Akbas, 2011: 181). Furthermore, any viable explanations for the crime drop must also accommodate the variation within crime types (Farrell, 2013) ${ }^{13}$; the variation within violence trends as identified in this paper. Existing crime drop theories that propose either a net reduction in the overall offending population, or a change in the criminal propensity of offenders, cannot speak to the variation in the timing and depth of the decline between acquaintance and stranger violence and their respective severity in relation to wounding. Therefore, attempts to explain the patterns found here should explore the role of opportunity theories including the security hypothesis (e.g. personal securitization) which have been found to successfully explain variation within/between property crime types (Tseloni et al., 2017; Farrell, 2016; Farrell et al., 2011b; Tseloni et al., 2010).

\section{Has violence fallen to the same extent across different demographic groups?}

This present study provides evidence (of which there is very little) on the drops in crime across different population groups and changes in victimisation inequalities (Hunter and Tseloni, 2016; Tseloni and Thompson, 2018). The overall violence drop was driven by a decline in incidents against young, and/or male individuals, perpetrated by people they 
knew at least by sight: with young males also responsible for the earlier sharp increases in violence (Sommers and Baskin, 1993; Cook and Laub, 2002; Farrell et al., 2015). By examining the trends of stranger and acquaintance violence over a longer time frame than previous studies, the key finding here is that young males were particularly responsible for both the increase as well as decrease in acquaintance violence. It also provides further confirmation that sex and age influence individuals' vulnerability (Hindelang et al., 1978) and inequalities in violent victimisation across different population groups (Walby et al., 2016: 1205).

In relation to the distributive justice within the crime drop, this study provides unique evidence of equitable falls in acquaintance but inequitable falls in stranger violence. Acquaintance violence rates declined the most for the highest risk demographic groups: men and the young. As a result, the acquaintance violence victimisation gap between men and women, as well as between those aged 16-24 years and those aged 25+ narrowed considerably between 1991 and 2013/14. In relation to crime inequalities at the peak year (1995), the ensuing acquaintance violence falls also benefited all age groups under 55 years old. A key finding of this study is that acquaintance violence drops were equitable: those who had suffered the most incidents experienced the greatest reductions. Stranger violence falls were less equitable between sexes; the victimisation gap between men and women remained stable, whereas - based on the uncapped incidents among strangers the falls were inequitable. Similarly, the falls in stranger violence were not equitable across age groups (with the exception of the 16-34 year olds).

III Is the fall in violence driven by a reduction in victimisation risk or crime concentration? 
Falls in both stranger and acquaintance violence incidence rates were driven by fewer victims over time. However, there are notable exceptions to this general conclusion which relate to the effect of capping the number of incidents in a series at five, as discussed below.

IV Do Home Office / ONS crime estimating methodology and analytic conventions affect these trends, and if so how?

Crime capping at five incidents seems to affect the estimated patterns in stranger violence but not in acquaintance violence. Removing the cap resulted in different peak and dip years for two crime types (overall stranger violence incidence rates and stranger violence incidence rates against men were both found to be statistically different between capped and uncapped data). Removing the cap also resulted in greater (non-statistically significant) volatility within some crime types (i.e. acquaintance violence incidence rates with wounding, stranger violence incidence rates with and without wounding, and stranger violence incidence rates against 16-24 year olds). This agrees with recent ONS evidence about uncapped series across all crime types (ONS, 2019). Furthermore, untruncated incidence trends were driven by changes in crime concentration for acquaintance violence with wounding, total stranger violence, with and without wounding, against men and women and the young (16-24 or 25-34 years old), especially in the last decade examined here.

In relation to the distributive justice issue discussed earlier, the untruncated data indicate that concentration (assuming prevalence in 1991 levels) in 2013/14 was higher than in 1991 for stranger violence without wounding and stranger violence against men, but was only statistically significant for stranger violence against men. However, the untruncated data should be interpreted with caution.

A limitation of this study is that it considered the distribution of the violence drop only in relation to crime concentration versus prevalence, and examined its equity only in 
relation to age groups and between sexes, without examining group composition (Tseloni and Thompson , 2018). Future work should therefore investigate issues of distributive justice in a more rigorous manner across all affected groups. Also, this study did not investigate causes or changes in opportunities but the disaggregation of trends serves as the foundations for this.

The above findings raise a number of additional puzzles that future studies may address: Why has there been a continuing fall in non-domestic violent crimes? Why did acquaintance violence fall earlier and more than stranger violence? Why has acquaintance violence without wounding fallen much more steeply than with wounding and why was the reverse observed in stranger violence? Why has there been a major fall in youth violence, not matched by those in other age groups? Why has acquaintance violence against men fallen dramatically to levels comparable to those against women, closing the victimisation gap?

Similar to existing prominent explanations of the falls in acquisitive crime, the above questions in relation to non-domestic violence can arguably be answered via hypotheses testing reductions in crime opportunities, following a situational crime perspective; for example, whether changes in routine activities, including drinking habits - especially by men and the young - and/or alcohol consumption regulations have reduced opportunities for violence. Previous research has hypothesised changing lifestyles to be a key driver of the decrease in cross-national homicide rates (Aebi and Linde, 2014). Therefore, the next step is to disaggregate trends in lifestyle by certain population characteristics to explore whether this is a driving factor in the drop of non-domestic, non-lethal violence evidenced in the present paper. Indeed, the composition of night-time economy patronage in England and Wales has experienced a demographic diversification in terms of a more even distribution of patrons' age and sex over time (Garius, 2016).

To conclude, the general and sustained declines in violence are good news, though this dramatic drop in violent crime is likely to be overshadowed by a high-profile increase in 
relatively rare, but "high-harm", weapon-related violent offences (in particular knife and gun crime) (ONS, 2018a). Whilst such high-harm incidents have attracted a large volume of media coverage, overarching levels of violence have remained stable since 2014 (ONS, 2018b): "with levels much lower than the peak seen in the mid-1990s" (Alexa Bradley cited in ONS, 2018a: 6). Therefore, the general drop in violent crime should not be lost amidst the understandable and quite proper concerns with increases in knife crime, which may be explained with careful analysis of specific offender and target populations and opportunities. Future research should apply this paper's hypotheses and methods to homicide trends which are not included in the CSEW in order to compare lethal and non-lethal violence trends.

\section{Funding}

This work was supported by the Economic and Social Research Council, Secondary Data Analysis Initiative (SDAI) Phase 2 [grant number ES/L014971/1]. 


\section{NOTES}

${ }^{1}$ Including rational choice and routine activity theory and situational crime prevention (Farrell et al., 2015).

${ }^{2}$ The other two nations of the UK, Northern Ireland and Scotland, have her own crime surveys.

3 We would like to acknowledge Home Office / Office for National Statistics for recommending and explaining the use of weights in the data.

${ }^{4}$ The $2017 / 18$ CSEW data set will provide the 98th percentile of victim incident counts as the highest number of crimes per crime type following ONS consultation on high frequency repeat victimisation (Farrier and Atchison, 2017).

${ }^{5}$ Other scholars often refer to this as "capped" data (e.g. see also Walby et al., 2016). The terms capped/truncated and uncapped/untruncated are used interchangeably in this study.

${ }^{6}$ The term 'concentration' has been established in the literature (Tseloni, 2014) but in their seminal study that first examined victimisation frequency in England and Wales, Trickett et al. (1992) used the term 'vulnerability'.

${ }^{7}$ Stranger violence peaked later than the year appearing in the ONS Appendix Tables (ONS, 2018) due to analysing here weighted data. For unweighted data series stranger violence peaked in 1995.

${ }^{8}$ Capping crime counts did not have a major effect on acquaintance violence incidence rates against 16-34 years old.

${ }^{9}$ The difference between truncated and untruncated stranger violence without wounding incidence rates at their different peak years was not statistically significant $(p=.093)$; the same holds for truncated and untruncated stranger violence with wounding $(\mathrm{p}=.164)$. 
${ }^{10}$ The increased number of stranger violence incidents against 35-44 and 55-64 year olds in recent years compared to 1991 was not statistically significant $(\mathrm{p}=.278$ and $\mathrm{p}=.181$, respectively).

${ }^{11}$ Untruncated incidence of stranger violence victimisation against $16-24$ years peaked in 2006/07 and followed a much steeper drop until its lowest (2012/13) rate compared to truncated. However, capped and uncapped peak or bottom rates were not statistically different $(\mathrm{p}=.174$ and $\mathrm{p}=.429$, respectively).

${ }^{12}$ With the benefit of examining a longer time period (i.e. 1991 until 2013/14) compared to Walby et al. (2016), our study incorporated any increases in violence and delayed violence falls, for example, in stranger violence.

13 This is known as Farrell's (2013) 'varying trajectories' test for a viable crime drop hypothesis which tests whether a hypothesis is compatible, or at least not in contradiction, with variation in the timing and trajectory of crime falls both between countries and between crime types. 


\section{References}

Aebi MF and Linde A (2012) Crime trends in Western Europe according to official statistics from 1990 to 2007. In: Van Dijk J, Tseloni A and Farrell G (eds) The International Crime Drop: New Directions in Research. Palgrave Macmillan, 37-75.

Aebi MF and Linde A (2014) The Persistence of Lifestyles: Rates and Correlates of Homicide in Western Europe from 1960 to 2010. European Journal of Criminology 11(5): $552-577$.

Ariel B. and Bland M (2019) Is Crime Rising or Falling? A Comparison of Police-Recorded Crime and Victimization Surveys. In: Deflem M and Silver DMD (eds) Methods of Criminology and Criminal Justice Research. Sociology of Crime, Law and Deviance, Vol. 24. Emerald Publishing Limited, 7-31.

Baumer EP and Wolff KT (2014) Evaluating Contemporary Crime Drop(s) in America, New York City, and Many Other Places. Justice Quarterly 31(1): 5-38.

Blumstein A (2000) Disaggregating the Violence Trends. In: Blumstein A and Wallman J (eds) The Crime Drop in America. Cambridge University Press, 13-44.

Blumstein A and Wallman J (2000) The Crime Drop in America. Cambridge University Press.

Britton A, Kershaw C, Osborne S and Smith K (2012) Underlying Patterns Within the England and Wales Crime Drop. In: Van Dijk J, Tseloni A and Farrell G (eds) The International Crime Drop: New Directions in Research. Palgrave Macmillan, 159-1181.

Clarke RV (1997) Introduction. In: Clarke RV (ed). Situational Crime Prevention. Guilderland, NY: Harrow and Heston, 1-43.

Clarke RV and Cornish DB (1985) Modeling Offenders' Decisions: A Framework for Research and Policy. In: Tonry M and Morris N (eds) Crime and Justice. Chicago, IL: 
University of Chicago Press, 147-185. Cook PJ and Laub JH (2002) After the Epidemic: Recent Trends in Youth Violence in the United States. Crime and Justice 29: 1-37.

Cohen LE and Felson M (1979) Social change and crime rate trends: A routine activity approach. American sociological review 44: 588-608.

Cornish DB (1994) The Procedural Analysis of Offending and Its Relevance for Situational Prevention. Crime Prevention Studies 3: 151-196.

Cornish DB and Clarke RV (1986) Situational Prevention, Displacement of Crime and Rational Choice Theory. In: Heal K and Laycock G (eds) Situational Crime Prevention: From Theory to Practice. HMSO.

Eisner M (2008) Modernity Strikes Back? A Historical perspective on the Latest Increase in Interpersonal Violence (1960-1990). International Journal of Conflict and Violence 2: $288-316$.

Farrell G (2013) Five Tests for a Theory of the Crime Drop. Crime Science 2(5): 1-8.

Farrell G (2016) Attempted Crime and the Crime Drop. International Criminal Justice Review 26(1): 21-30.

Farrell G, Clarke RV, Ellingworth D and Pease K (2005) Of Targets and Supertargets: A Routine Activities Theory of High Crime Rates. Internet Journal of Criminology 33: 1-25.

Farrell, G., Laycock, G. and Tilley, N. (2015), 'Debuts and Legacies: The Crime Drop and the Role of Adolescence-limited and Persistent Offending', Crime Science, 4(1): 16.

Farrell G and Pease K (2007) The Sting in the British Crime Survey Tail: Multiple Victimisation. In: Maxfield M and Hough M (eds) Surveying Crime in the Twenty First Century, Crime Prevention Studies. Cullompton: Willan, 33-53.

Farrell G, Phillips C and Pease K (1995) Like Taking Candy: Why Does Repeat Victimisation Occur? British Journal of Criminology 35(3): 384-399. 
Farrell, G., Tilley, N. and Tseloni, A. (2014), 'Why the Crime Drop?' Crime and Justice, 43(1): 421-490.

Farrell, G., Tilley, N., Tseloni, A. and Mailley, J. (2010), 'Explaining and Sustaining the Crime Drop: Clarifying the Role of Opportunity-Related Theories', Crime Prevention and Community Safety, 12(1): 24-41. DOI: 10.1057/cpcs.2009.20.

Farrell, G., Tseloni, A., Tilley, N. and Mailley, J. (2011a), 'The Crime Drop and the Security Hypothesis', Journal of Research in Crime and Delinquency, 48(2): 147-175.

Farrell, G., Tseloni, A. and Tilley, N. (2011b), 'The Effectiveness of Vehicle Security Devices and their Role in the Crime Drop', Criminology and Criminal Justice, 11: 21-35. DOI: $10.1177 / 1748895810392190$.

Farrier C and Aitchison F (2017) 'CSEW: An update' Presentation at the Crime Surveys User Conference $2017 . \quad$ Available online at https://www.ukdataservice.ac.uk/media/605036/aitchisonfarrier.pdf

Felson M (2012) The Structure of Angry Violence. In: Tilley N and Farrell G (eds) The Reasoning Criminologist: Essays in honour of Ronald. V. Clarke. Oxon: Routledge Publishing, 205-211.

Felson M and Steadman H (1983) Situational Factors in Disputes Leading to Criminal Violence. Criminology 21: 59-74.

Felson R (1996) Big people hit little people: Sex differences in physical power and interpersonal violence. Criminology 34(3): 433-452.

Felson R (1997) Routine Activities and Involvement in Violence as Actor, Witness, or Target. Violence and Victims 12(3): 209-221.

Flatley J (2014) British Crime Survey. In: Bruinsma G and Weisburd D (eds) Encyclopedia of Criminology and Criminal Justice. New York: Springer-Verlag, 194-203. 
Garius, L.L. (2016), Opportunities for Physical Assault in the Night-Time Economy in England and Wales, 1981-2011/12. PhD Thesis, Loughborough University, UK. Available online at https://dspace.lboro.ac.uk/dspace-jspui/handle/2134/20427

Griffiths MD and Sutton M (2015) Screen time and crime: the crime substitution hypothesis revisited. Education and Health 33(4): 85-87.

Gurr TR (1981) Historical Trends in Violent Crime: A Critical Review of the Evidence. In: Tonry M and Morris N (eds) Crime and Justice: An Annual Review of Research. University of Chicago Press, 295-353.

Hall W (2013) Did the Elimination of Lead from Petrol Reduce Crime in the USA in the 1990s?,F1000 Research, 2(156): 1-9.

Hayward K (2007) Situational Crime Prevention and its Discontents: Rational Choice Theory versus the 'Culture of Now. Social Policy \& Administration 41(3): 232-250.

Hebenton B (2011) From offender to situation: The 'cold' approach to sexual violence prevention? International journal of law and psychiatry 34(3): 141-148.

Hindelang MJ, Gottfredson MR and Garofalo J (1978) Victims of Personal Crime: An Empirical Foundation for a Theory of Personal Victimization. Cambridge, MA: Ballinger. Hunter, J. and Tseloni, A. (2016), 'Equity, Justice and the Crime Drop: The case of Burglary in England and Wales', Crime Science, 5(1): 3.

Ignatans D and Pease K (2016) On Whom Does the Burden of Crime Fall Now? Changes Over Time in Counts and Concentration. International Review of Victimology 22(1): 5563.

Indermaur D (1999) Situational prevention of violent crime: Theory and practice in Australia. Studies on Crime and Crime Prevention 8: 71-87.

Killias M and Lanfranconi B (2012) The Crime Drop Discourse - or the Illusion of Uniform Continental Trends: Switzerland as a Contrasting Case. In: Van Dijk J, Tseloni A and 
Farrell G (eds) The International Crime Drop: New Directions in Research. Palgrave Macmillan, 268-278.

Knepper P (2015) Falling Crime Rates: What Happened Last Time. Theoretical Criminology 19(1): 59-76.

LaFree G, Curtis K and McDowall D (2015) How Effective are Our 'Better Angels'? Assessing Country-Level Declines in Homicide Since 1950. European Journal of Criminology 12(4): 482-504.

Lappi-Seppälä T and Lehti M (2014) Cross-Comparative Perspectives on Global Homicide Trends. In: Tonry M (ed) Why Crime Rates Fall and Why They Don't. University of Chicago Press.

Machin S and Meghir C (2004) Crime and Economic Incentives. The Journal of Human Resources 39(4): 958 - 979.

McClave JT and Sincich TT (2017) Statistics, $13^{\text {th }}$ Edition. Pearson.

Mooney J (2003) It's the Family Stupid: Continuities and Reinterpretation of the Dysfunctional Family as the Cause of Crime in Three Political Periods. In: Matthews R and Young J (eds) The New Politics of Crime and Punishment. Willan Books, 100-111.

Mooney G and Jan S (1997) Vertical Equity: Weighting Outcomes? Or Establishing Procedures? Health Policy 39(1): 79-87.

Mooney J and Young J (2006) The Decline in Crime and the Rise of Anti-social Behaviour Journal of Community and Criminal Justice 53(4): 397-407.

Morgan N (2014) The Heroin Epidemic of the 1980s and 1990s and its Effect on Crime Trends Then and Now. Home Office Research Report 79. London.

Nilsson A, Estrada F, Bäckman O (2017) The Unequal Crime Drop: Changes over Time in the Distribution of Crime among Individuals from Different Socioeconomic Backgrounds. European Journal of Criminology 14(5): 586 - 605. 
ONS (Office for National Statistics) (2015) Crime in England and Wales: Year ending March 2015. Statistical Bulletin. London

ONS (Office for National Statistics) (2017) Crime in England and Wales: Year ending December 2016. Statistical Bulletin. London.

ONS (Office for National Statistics) (2018) Crime in England and Wales: Appendix Tables. Year ending June 2018. London: Office for National Statistics.

ONS (Office for National Statistics) (2018a) Crime in England and Wales: Year ending December 2017. London: Office for National Statistics.

ONS (Office for National Statistics) (2018b) The Nature of Violent Crime in England and Wales: Year ending March 2017. London: Office for National Statistics.

ONS (Office for National Statistics) (2019) Improving Victimisation Estimates Derived from the Crime in England and Wales. London: Office for National Statistics.

Ozer MM and Akbas H (2011) The Application of Situational Crime Prevention to Terrorism. Turkish Journal of Police Studies 13 (2): 179 - 194.

Pinker S (2011) The Better Angels of Our Nature: Why Violence Has Declined. New York: Viking.

Rawls J (1999) A Theory of Justice. Cambridge: Harvard University Press.

Scott MS and Dedel K (2006) 'Assaults in and around Bars. Guide No 1. Second edition.' Problem-Oriented Guides for Police Problem-Specific Guides Series Guide No. 1. Available online at http://www.popcenter.org/problems/pdfs/Assaults_in_and_Around_Bars.pdf

Sommers I and Baskin DR (1993) The Situational Context of Violent Female Offending. Crime and Delinquency 30(2): 136-162.

The Economist (2011, Dec 15), 'Good News is No News', The Economist. Available online at http://www.economist.com/node/18775436. 
Thompson R (2014) Understanding Theft from the Person and Robbery of Personal Property

Victimisation Trends in England and Wales, 1994 - 2010/11. PhD Thesis, Nottingham Trent University, UK.

Thorpe K (2007) Multiple and Repeat Victimisation. In: Jansson K, Budd S, Lovbakke J, Moley S and Thorpe K (eds) Attitudes, Perceptions and Risks of Crime, Home Office Statistical Bulletin 19/07. London: Home Office, 81-98.

Tilley, N., Farrell, G. and Clarke, R.V. (2015), 'Target Suitability and the Crime Drop', in M.A. Andresen and G. Farrell, eds, The Criminal Act, 59-76. Palgrave MacMillan.

Tilley, N., Farrell, F. and Tseloni, A. (2018), 'Doing Quantitative Criminological Research: The Crime Drop', in P. Davies and P. Francis, eds, Doing Criminological Research Third Edition. Sage Publications.

Tilley, N. and Tseloni, A. (2016), 'Choosing and Using Statistical Sources in Criminology What Can the Crime Survey for England and Wales Tell Us?' Legal Information Management, 16(2): 78-90. Cambridge University Press. DOI: $10.1017 /$ S1472669616000219.

Tonry M (2014) Why Crime Rates Are Falling throughout the Western World. Crime and Justice 43: 1-63.

Trickett A, Osborn DR, Seymour J and Pease K (1992) What is Different About High Crime Areas? British Journal of Criminology 32: 81-89.

Tseloni, A. (2014), 'Understanding Victimization Frequency', in G. Bruinsma and D. Weisburd, eds, Encyclopedia of Criminology and Criminal Justice (ECCJ), 5370-5382. Springer-Verlag.

Tseloni, A. (2016), 'Stranger and Acquaintance Violence in England and Wales: Trends, Equity and Threats.' Presentation at the Crime Surveys Users Meeting, Royal Statistical Society, London. 9 Dec. 2016. 
Tseloni, A., Farrell, G., Thompson, R., Evans, E. and Tilley, N. (2017), 'Domestic Burglary Drop and the Security Hypothesis', Crime Science, 6(3): 1-16. DOI: 10.1186/s40163-0170064-2 Open Access.

Tseloni, A., Mailley, J., Farrell, G. and Tilley, N. (2010), 'Exploring the International Decline in Crime Rates', European Journal of Criminology, 7(5): 375-394. DOI: $10.1177 / 1477370810367014$.

Tseloni, A. and Thompson, R. (2018), 'Household- and Area-level Differences in Burglary Risk and Security Availability over Time', in A. Tseloni, R. Thompson, and N. Tilley, eds, Reducing Burglary, 107-164. Springer.

Van Dijk J, Kesteren, JV and Smit P (2007) Criminal Victimisation in International Perspective. Available online at http://repository.tudelft.nl/view/wodc/uuid:e9af6c3f-260a$\underline{4 d 5 c-9 d 3 f-1 b 2100 a 233 f 0 / ~}$

Van Dijk, J. and Tseloni, A. (2012), 'Global Overview: International Trends in Victimization and Recorded Crime', in J. Van Dijk, A. Tseloni, and G. Farrell, eds, The International Crime Drop: New Directions in Research, 286-299. Palgrave Macmillan.

Walby S, Towers J and Francis B (2016) Is Violent Crime Increasing or Decreasing? A New Methodology to Measure Repeat Attacks Making Visible the Significance of Gender and Domestic Relations. British Journal of Criminology 56(6): 1203-1234. 


\section{Diagrams and Tables}
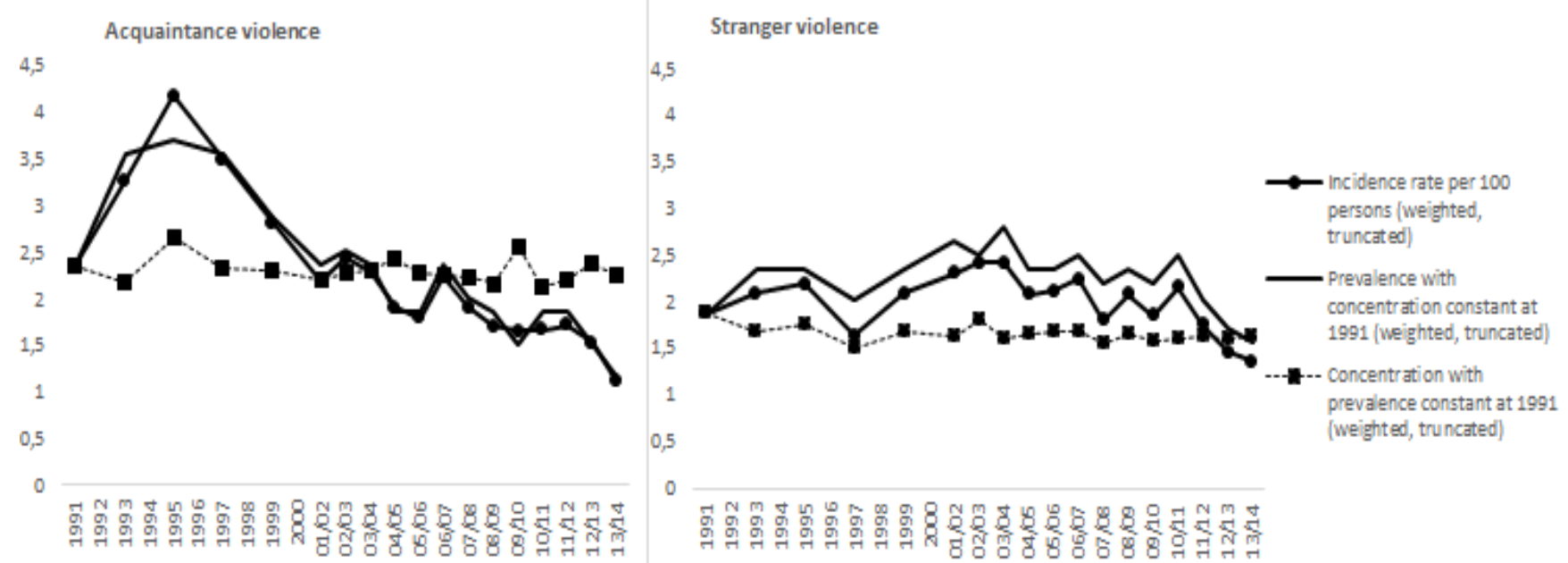

Figure 1. Trends in violence victimisation rate (weighted, truncated).

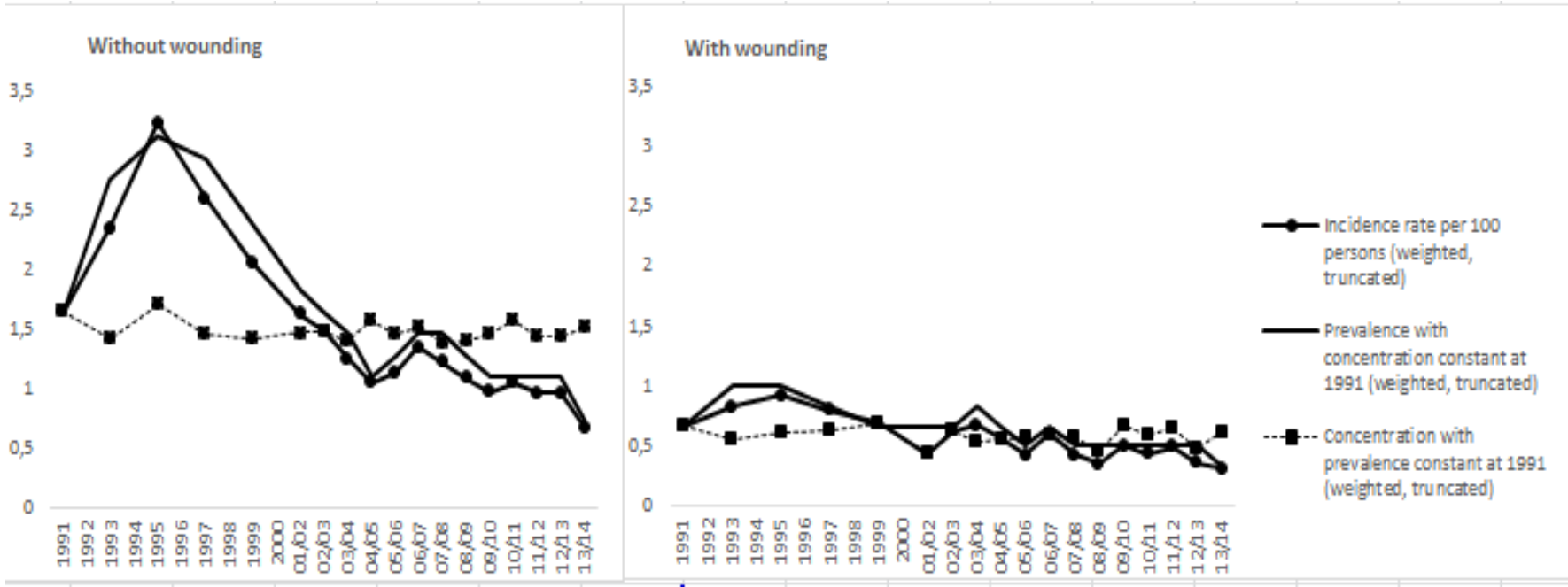

Figure 2. Acquaintance violence victimisation incidence with and without wounding (weighted, truncated).

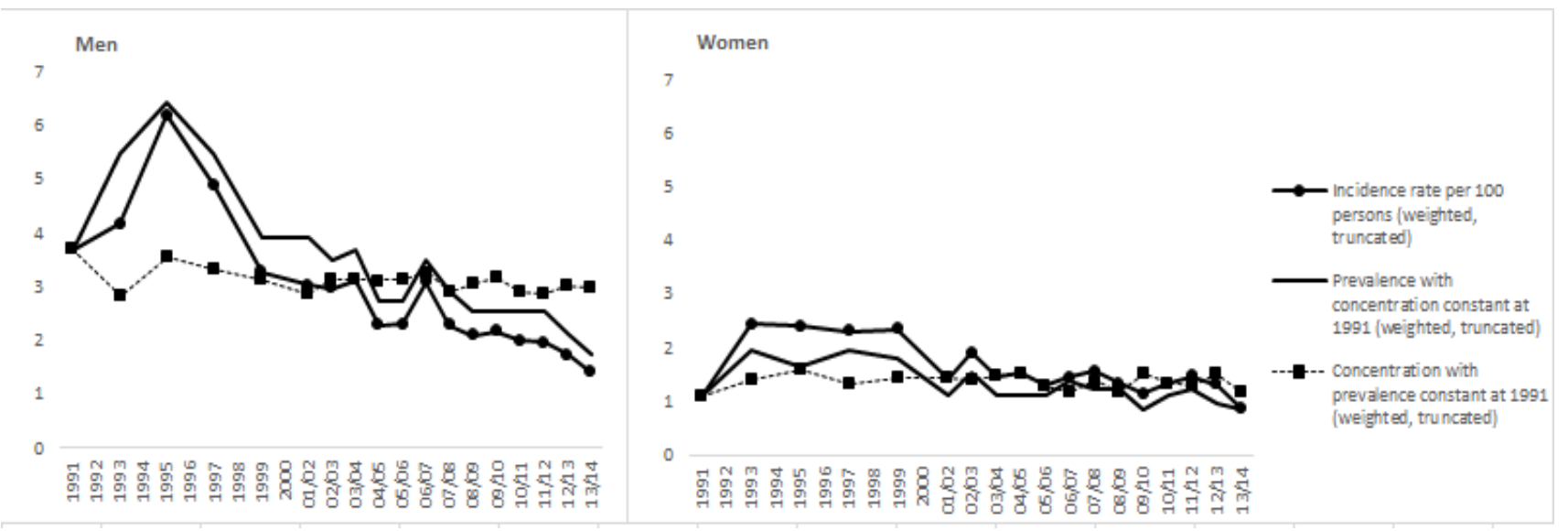

Figure 3. Acquaintance violence victimisation incidence against men and women (weighted, truncated). 


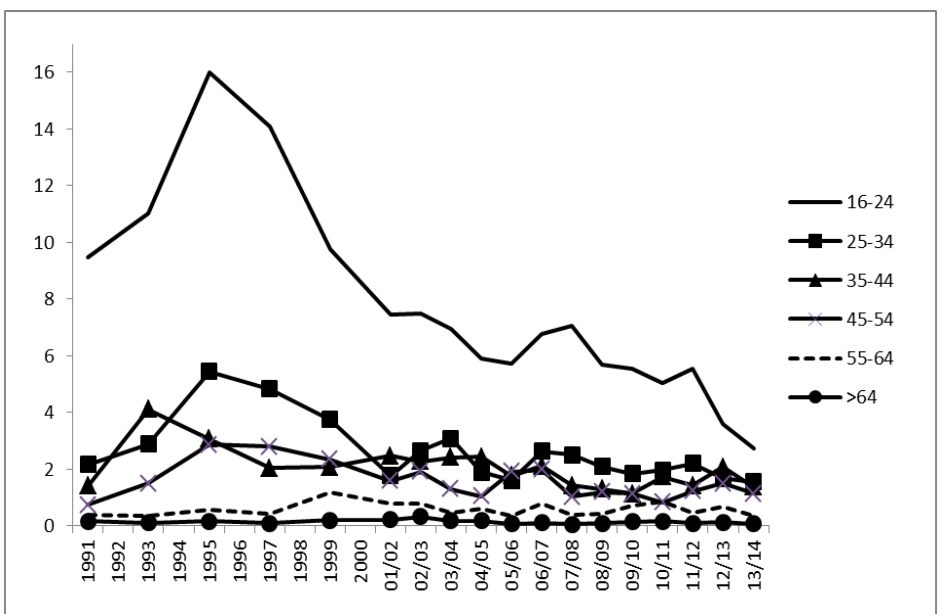

Figure 4. Acquaintance violence per 100 persons by age group - Incidence rate (weighted, truncated).

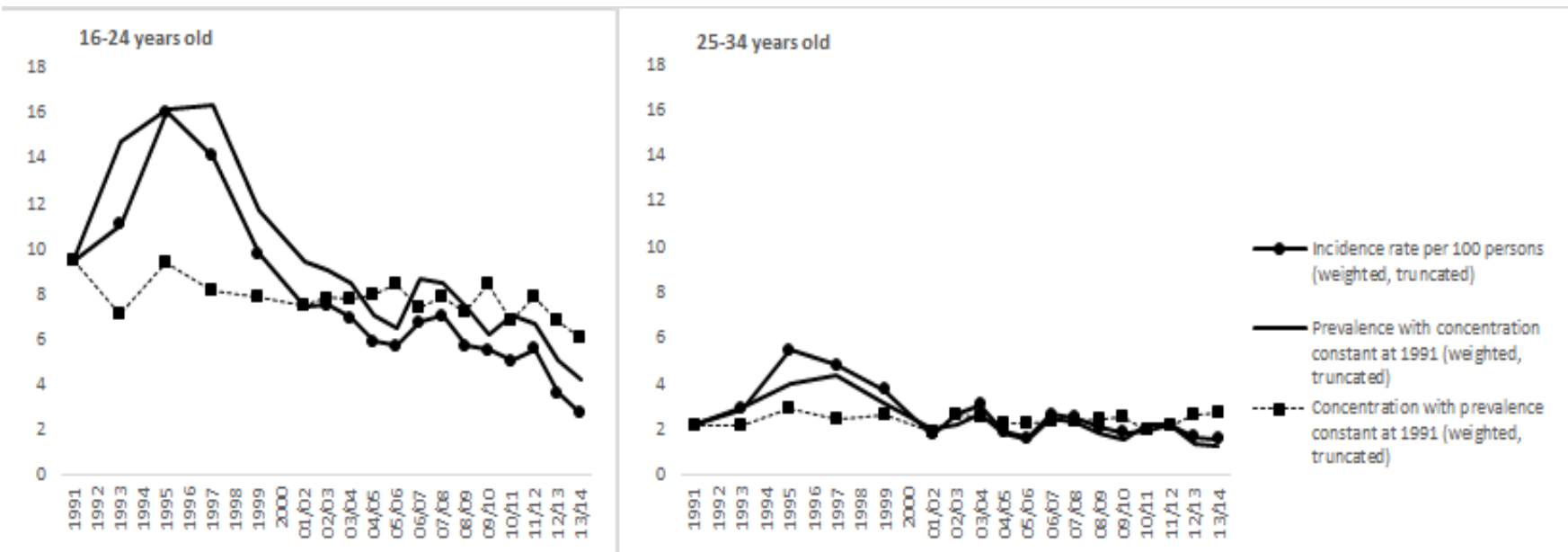

Figure 5. Acquaintance violence victimisation incidence against 16-24 years old and 25-34 years old (weighted, truncated).

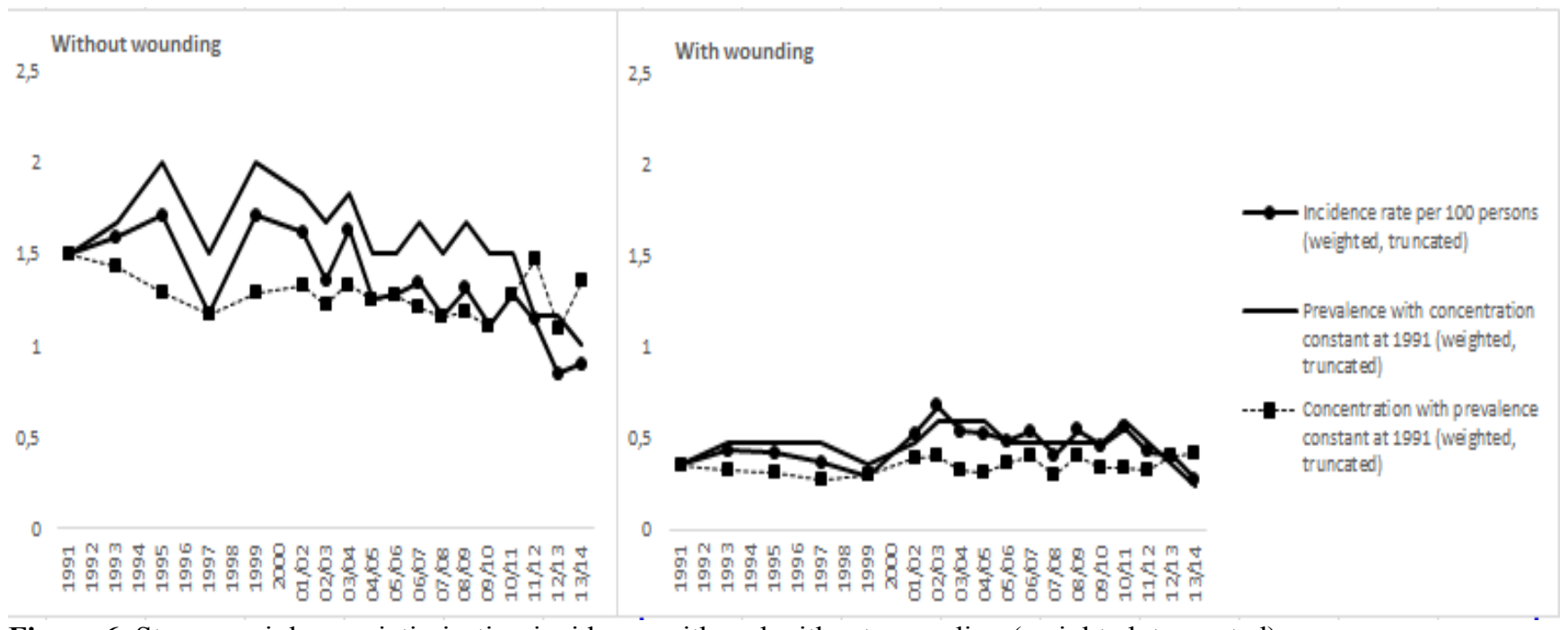

Figure 6. Stranger violence victimisation incidence with and without wounding (weighted, truncated). 


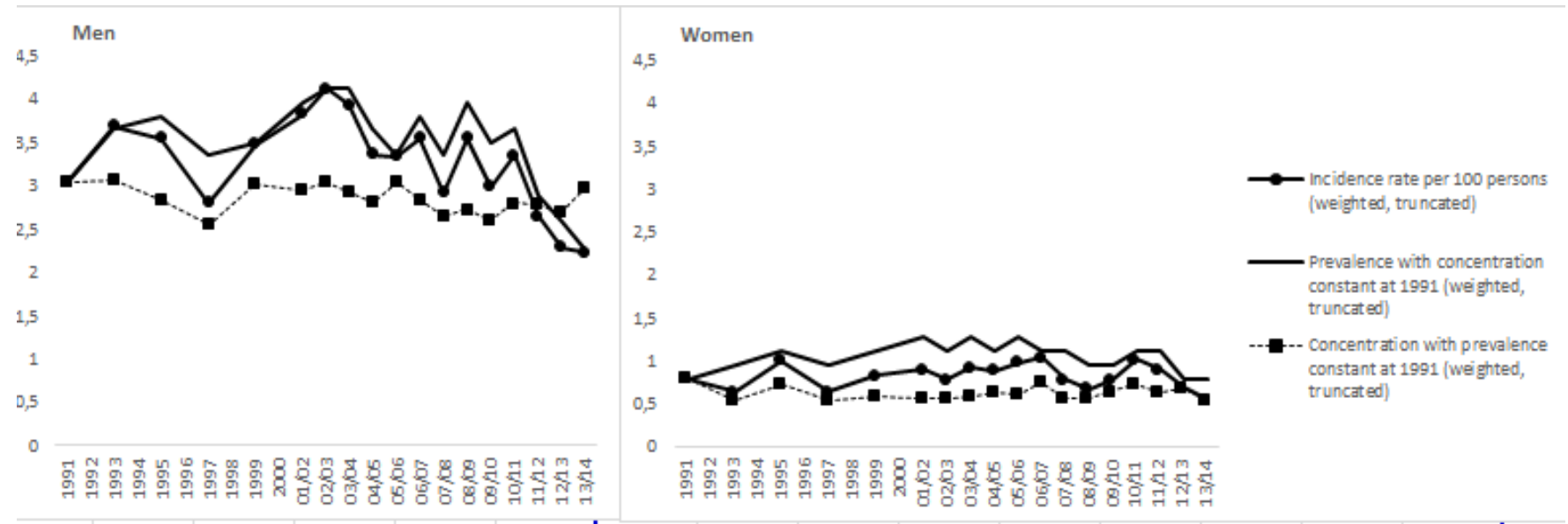

Figure 7. Stranger violence victimisation incidence against men and women (weighted, truncated).

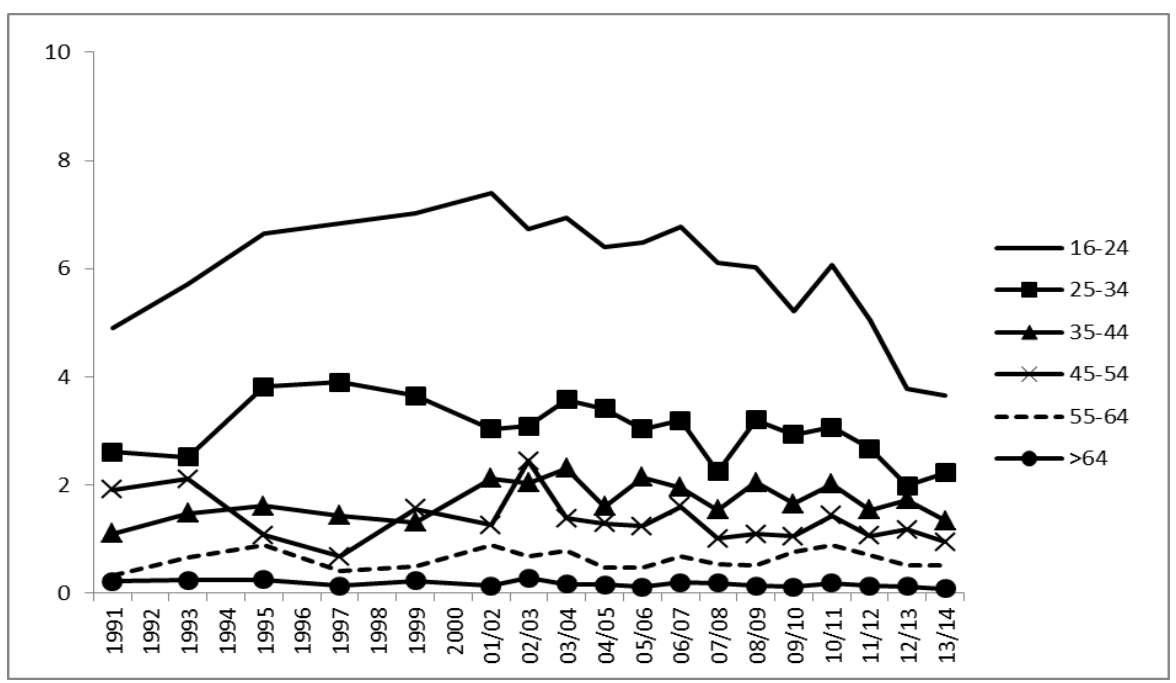

Figure 8. Stranger violence per 100 persons by age group - Incidence rate (weighted, truncated).

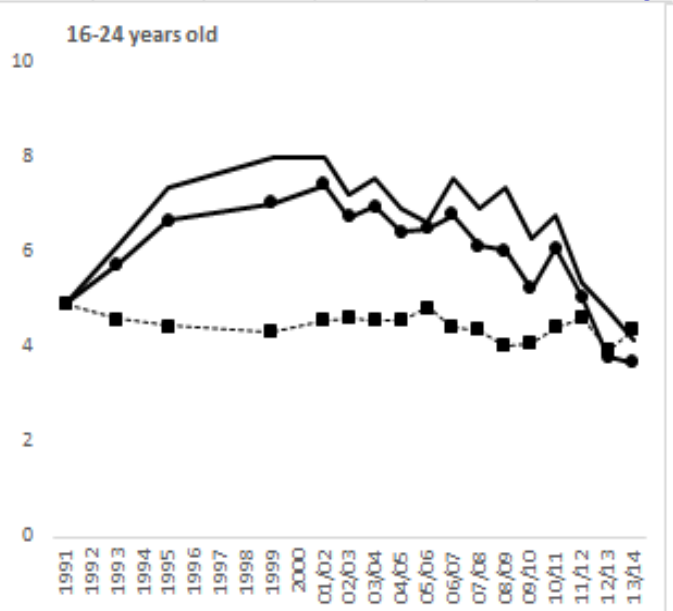

25-34 years old

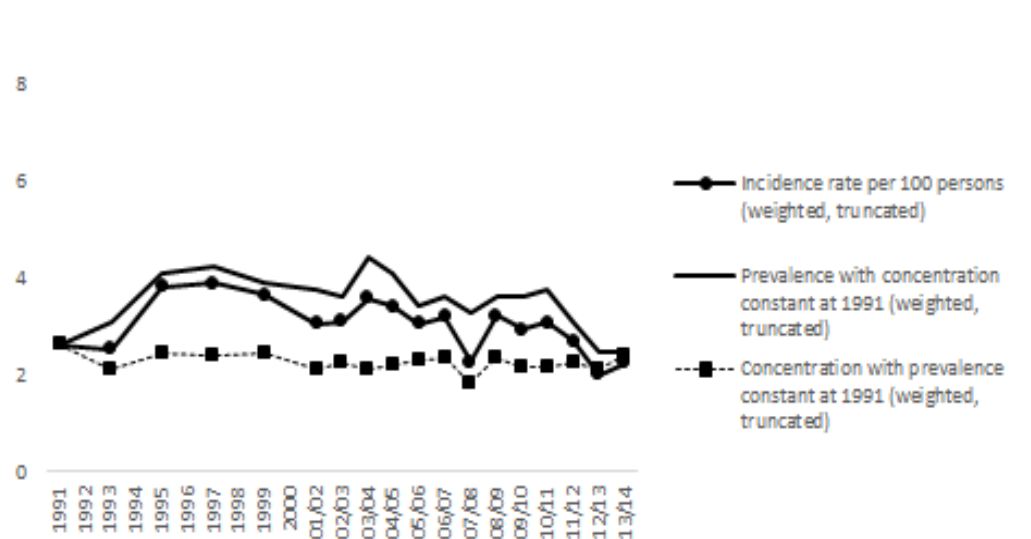

Figure 9. Stranger violence victimisation incidence against 16-24 years old and 25-34 years old (weighted, truncated). 


\section{Appendix}

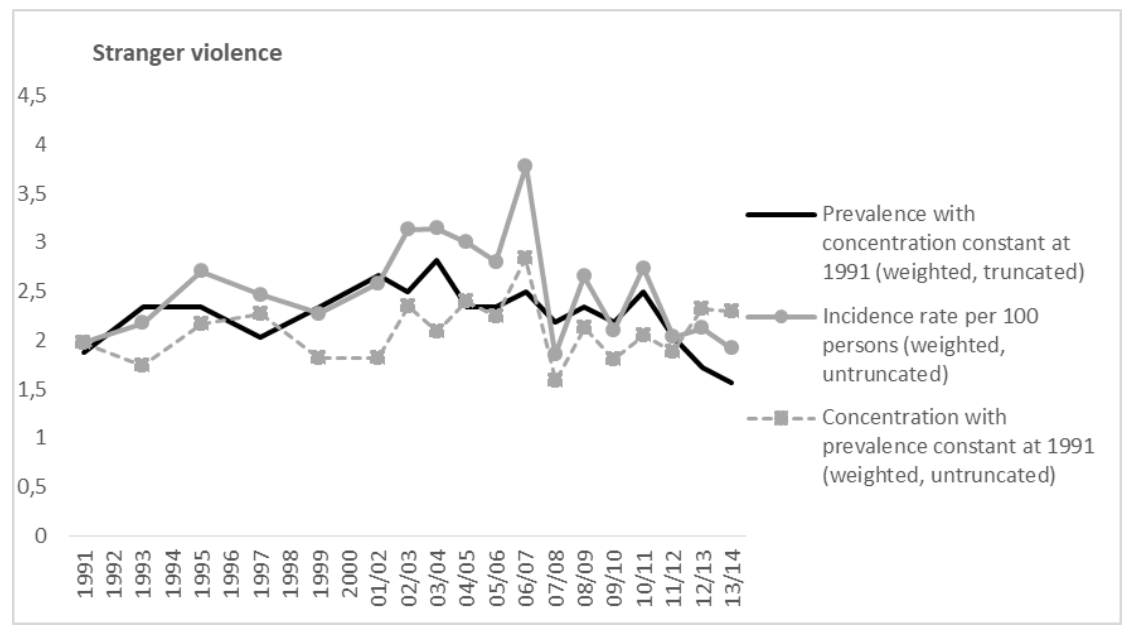

Appendix Figure 1. Untruncated trends in stranger violence victimisation rate (weighted).

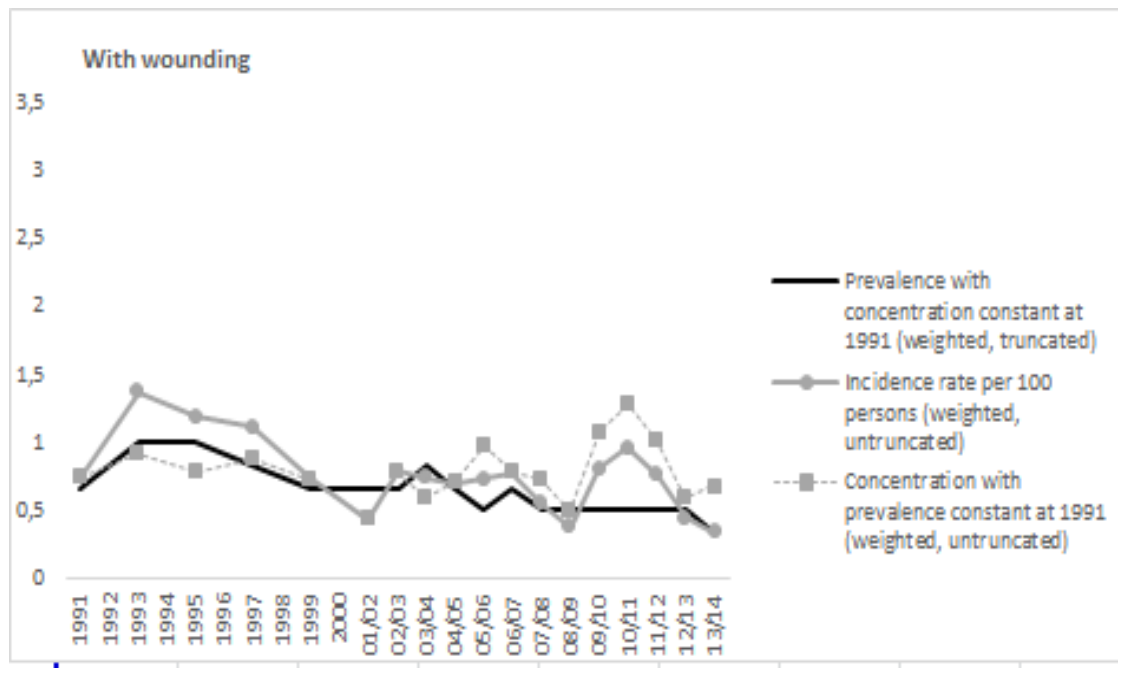

Appendix Figure 2. Untruncated trends in acquaintance violence with wounding (weighted). 


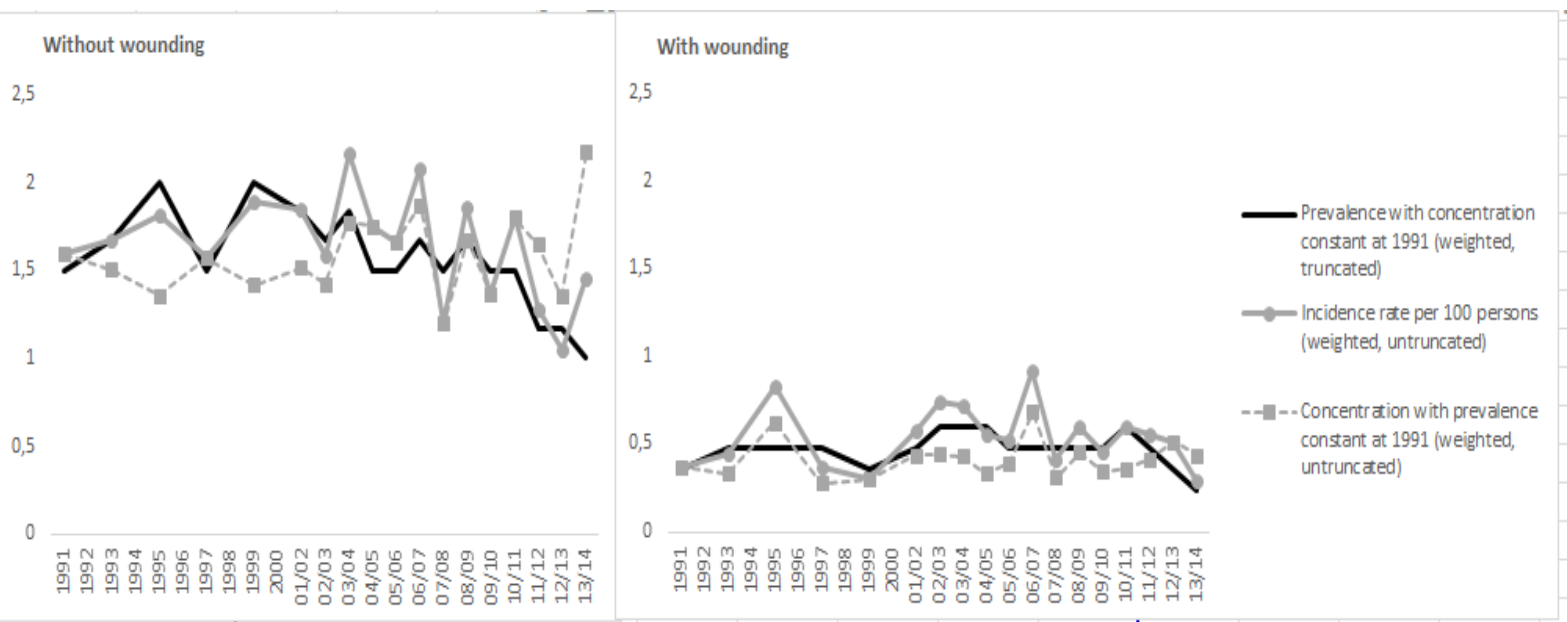

Appendix Figure 3. Untruncated trends in stranger violence victimisation incidence with and without wounding (weighted).

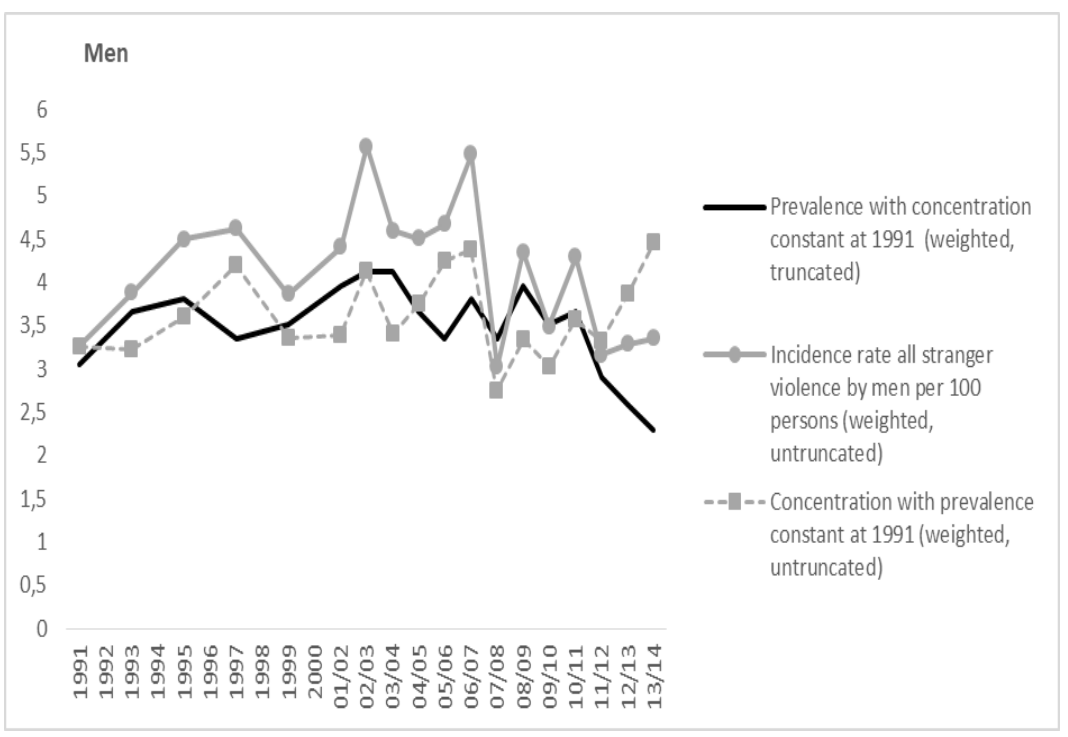

Appendix Figure 4. Untruncated trends in stranger violence victimisation incidence against men (weighted). 


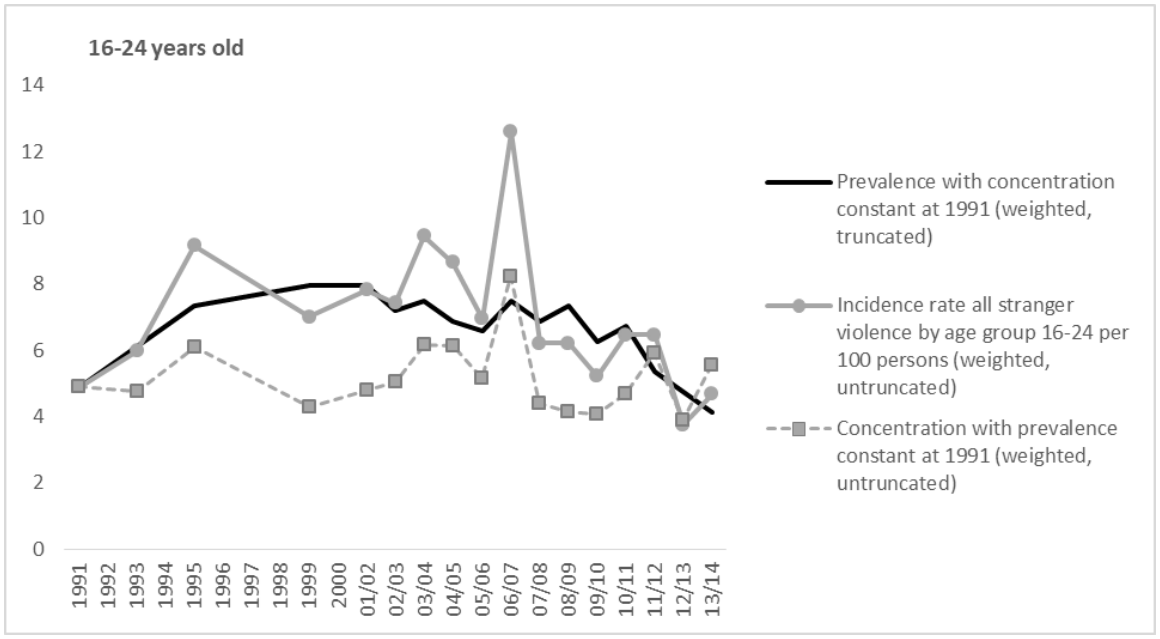

Appendix Figure 5. Untruncated trends in stranger violence victimisation incidence against 16-24 years old (weighted). 